\title{
Influence of Prunus spinosa L. shrub on the grassland vegetation in western Romania
}

\author{
Veronica SĂR̆ȚEANU, Alexandru MOISUC
}

Banat's University of Agricultural Sciences and Veterinary Medicine, Calea Aradului 119, 300645

Timişoara, Romania; e-mail: vera_s_vera@yahoo.com

\begin{abstract}
Prunus spinosa L. is a shrub species that is leading the permanent grassland to the shrubland successional phase. This species has a great occurrence in western Romania and is difficult to control it because it has a great ability of vegetative spreading from roots. The massive presence of this species in some grassland is due mainly to the abandonment and to the diminishing of the livestock. The vegetation was analysed with the linear point-quadrat method. This work has in view to analyse the influence of this species on some vegetation parameters as species richness, number of grasses, legumes and other species, contribution of grasses, legumes and other species, biodiversity indexes (Shannon $-H^{\prime}$ and Simpson $-D$ and pastoral value $V P$.
\end{abstract}

Key words: correlation, floristic composition, grassland, Prunus spinosa L., vegetation

\section{INTRODUCTION}

Prunus spinosa L. (blackthorn) belongs to Prunus genus from the Rosaceae family. It grows wildly in various regions (MARAKOGLU et al., 2005) as Europe, Asia, North Africa and North America from lowland to highland (1000 m) (PÂRVU, 2000). It has a great capacity of vegetative spreading, invading the open land areas forming dense and spiny brushwood (PÂRVU, 2000).

It was observed that after two years of management by hay cutting and shrub (P. spinosa and Rubus fruticosus) clearance, the floristic species richness doubled. Shrub clearance also prevented $R$. fruticosus and $P$. spinosa from further smothering the grassland flora.

Temperate woodlands and meadows support a variety of thorny shrubs (such as blackthorn Prunus spinosa L., Crataegus spp. and Rosa spp.) that are lightdemanding and occur mostly along forest edges (STORTELDER et al., 1999 cited by BAKKER et al., 2004).

Another good method for the maintenance over the years of a relatively constant coverage of $P$. spinosa in grassland without clearing the land is the grazing with goats (RAHMANN, 2004). 


\section{MATERIAL AND METHODS}

The researches presented in this work were carried out during 2003-2008 on two permanent grasslands, one steppe type from Cheglevici and one forest steppe type from Surduc (Timiş County, western Romania).

The grassland from Cheglevici is characterised by a chernozem type soil with a $\mathrm{pH}$ of 6.95 , the average yearly temperature is $10.5^{\circ} \mathrm{C}$, the multiannual rainfall amount is $541.4 \mathrm{~mm}$ and the altitude is $89 \mathrm{~m}$ a.s.l.

The grassland from Surduc has a brown soil with a $\mathrm{pH}$ of 5.38, the multiannual temperature is 10.4 , the average yearly rainfall amount is $690.7 \mathrm{~mm}$ and the altitude is $242 \mathrm{~m}$ a.s.1.

The coverage index of $P$. spinosa was determined on a permanent quadrate transect of 100 square meters. The herbaceous vegetation data was determined using the linear point-quadrat method (DAGET and POISSONET, 1971). The vegetation parameters analysed were: species richness, number of grasses, legumes and other species number, contribution of grasses, legumes and other species, Shannon index $H^{\prime}$, Simpson index $D$ and pastoral value $V P$ on $0-100$ scale.

The specific contribution $S C \%$ was calculated considering the number of contacts and represents the report between the specific frequency of a given species and the total of the specific frequencies of the taxa from the relevé using the following formula:

$$
C S_{i} \%=\left(F S_{i} / \Sigma F S_{i}\right) \cdot 100
$$

where:

$F S_{i} \quad-$ specific frequency of the species $i$;

$\Sigma F S_{i}$ - the sum of the specific frequencies of the taxons from a relevé (DAGET and POISSONET, 1971).

Shannon's entropy and Simpson index are used for the estimation of the biodiversity.

Shannon's entropy $H^{\prime}$ is calculated using the formula:

$$
H^{\prime}=-\sum_{i=1}^{S} p_{i} \ln p_{i}
$$

where:

$S$ - species number from the analysed sample (species richness);

$p_{i}=$ proportion of $i$ species from $S$, respectively $n_{i}: N$ (BEALS et al., 2000). 
Simpson's index $D$ was calculated using the next formula:

$$
D=\sum\left(n_{i} / N\right)^{2}=\sum_{i=1}^{S} p_{i}^{2}
$$

where:

$n_{i}-$ total individual number of the species $i$;

$N$ - total number of the individual of the species from the sample (BEALS et al., 1999).

The pastoral value $V P$ was calculated after the following formula:

$$
V P=0.2 \Sigma\left(C S_{i} I S_{i}\right)
$$

where:

$C S_{i}-$ specific contribution of the species $i$;

$I S_{i}-$ specific quality index of the species $i$ (DAGET and POISSONET, 1971).

The statistical method used is Pearson's correlation coefficient $r$.

\section{RESULTS AND DISCUSSION}

Grassland from Cheglevici is dominated by Cynodon dactylon and Bromus hordeaceus. In the vegetation sward have an important contribution Achillea millefolium, Polygonum aviculare, Geranium pratense and Prunus spinosa (Tab. 1).

The species number was comprised between 21 and 30, respectively the grasses number was between 3 and 4, legumes between 2 and 4 and species from other botanical families between 15 and 20 . The contribution of the grasses is relatively low being comprised between $17.65 \%$ and $35.83 \%$. The contribution of legumes was comprised between $0.82 \%$ and $6.95 \%$, and the $S C \%$ of the species from other botanical families has a high value, being comprised between $62.49 \%$ and $75.59 \%$. $H^{\prime}$ values obtained were characteristic for an average to high biodiversity (2.36-2.96), but the values obtained for $D$ were typical for high diversity (0.060.14). The high values of biodiversity are due to the great number of annual weeds. The values calculated for $V P$ were very low (14.58-18.93) highlighting that the species without or with low forager value have the most important contribution in the grassland sward.

Grassland from Surduc is dominated by Agrostis tenuis and Festuca rupicola, there being present in an important amount Holcus lanatus, Plantago lanceolata and Daucus carota (Tab. 1). The species richness was comprised between 21 and 25 , respectively the grasses number was between 3 and 5, legumes between 1 and 2 
Table 1. Synthesis of the taxa from the grasslands from Cheglevici and Surduc (2003-2008)

\begin{tabular}{l|l}
\multicolumn{1}{c|}{ Cheglevici } & \multicolumn{1}{c}{ Surduc } \\
\hline $\begin{array}{l}\text { Grasses: } \\
\text { Cynodon dactylon, Bromus hordeaceus, Alopecurus } \\
\text { pratensis, Lolium perenne, Poa pratensis, Poa an- }\end{array}$ & $\begin{array}{l}\text { Agrostis tenuis, Festuca rupicola, Holcus lana- } \\
\text { tus, Festuca pratensis, Anthoxanthum odoratum }\end{array}$ \\
\cline { 2 - 3 } &
\end{tabular}

Legumes:

Legumes:

Medicago lupulina, Lotus corniculatus, Lathyrus:Lotus corniculatus, Medicago lupulina tuberosus, Trifolium pratense, Ononis arvensis, : Vicia angustifolia, Vicia cracca, Vicia grandiflora

\begin{tabular}{|c|c|}
\hline $\begin{array}{l}\text { Juncaceae and Cyperaceae: } \\
\text { Carex praecox, Luzula avensis }\end{array}$ & $\begin{array}{l}\text { Juncaceae and Cyperaceae: } \\
\text { none }\end{array}$ \\
\hline Other species: & Other species: \\
\hline $\begin{array}{l}\text { Achillea millefolium, Daucus carota, Geranium } \\
\text { pratense, Cirsium undulatum, Cichorium intybus, } \\
\text { Eryngium campestre, Carlina vulgaris, Polygonum } \\
\text { aviculare, Dipsacus fullonum, Xanthium italicum, } \\
\text { Agrimonia eupatoria, Scabiosa ochroleuca, Plan- } \\
\text { tago lanceolata, Symphythum officinale, Pastinaca } \\
\text { sativa, Inula helenium, Verbascum phlomoides, } \\
\text { Linaria vulgaris, Convolvulus arvensis, Capsella } \\
\text { bursa pastoris, Carduus acanthoides, Chenopodium } \\
\text { album, Taraxacum officinale, Lamium purpureum, } \\
\text { Silene alba, Myosotis arvensis, Veronica hederifo- } \\
\text { lia, Adonis estivalis }\end{array}$ & $\begin{array}{l}\text { Erygeron anuus, Mentha arvensis, Bellis per- } \\
\text { ennis, Hieracium pilosella, Thymus serpyllum, } \\
\text { Gallium verum, Euphorbia cyparissias, Ery- } \\
\text { geron canadensis, Daucus carota, Plantago } \\
\text { lanceolata, Hypericum maculatum, Rumex ace- } \\
\text { tosella, Pimpinela major, Viola odorata, Poten- } \\
\text { tilla argentea, Ranunculus acris, Eupatorium } \\
\text { cannabinum, Rudbeckia laciniata, Cirsium } \\
\text { arvense, Veronica chamaedrys, Pimpinela ma- } \\
\text { jor, Carpesium cernuum, Leontodon autum- } \\
\text { nalis, Carthamus lanatus }\end{array}$ \\
\hline Shrubs: & Shrubs: \\
\hline Rosa canina, Prunus spinosa & $\begin{array}{l}\text { Prunus spinosa, Rosa canina, Rubus caesius, } \\
\text { Crataegus monogyna }\end{array}$ \\
\hline
\end{tabular}

and species from other botanical families between 15 and 21. The contribution of the grasses is high being comprised between $50.62 \%$ and $70 \%$. The contribution of the legumes was comprised between $0.4 \%$ and $5.42 \%$ and the $S C \%$ of the species from other botanical families was between $29.6 \%$ and $52.48 \%$. $H^{\prime}$ values obtained were characteristic for an average biodiversity (2.04-2.53), but the values obtained for $D$ were typical for high diversity $(0.12-0.21)$. The values calculated for $V P$ were low to medium (26.94-41.04).

In Figure 1 is presented the evolution of $P$. spinosa coverage index along the time during the study. The values registered in Surduc $(9.63-31.56 \%)$ were lower than in Cheglevici (3.75-15.27\%).

The analysis of the influence of the P. spinosa coverage index on the vegetation of both grasslands was realised with the help of the correlation coefficients $r$ and determination coefficients $R^{2}$ among $P$. spinosa coverage index and species richness, number of grasses, legumes and other species, contribution of grasses, legumes and other species, $H^{\prime}, D$ and $V P$ (Tab. 2). 


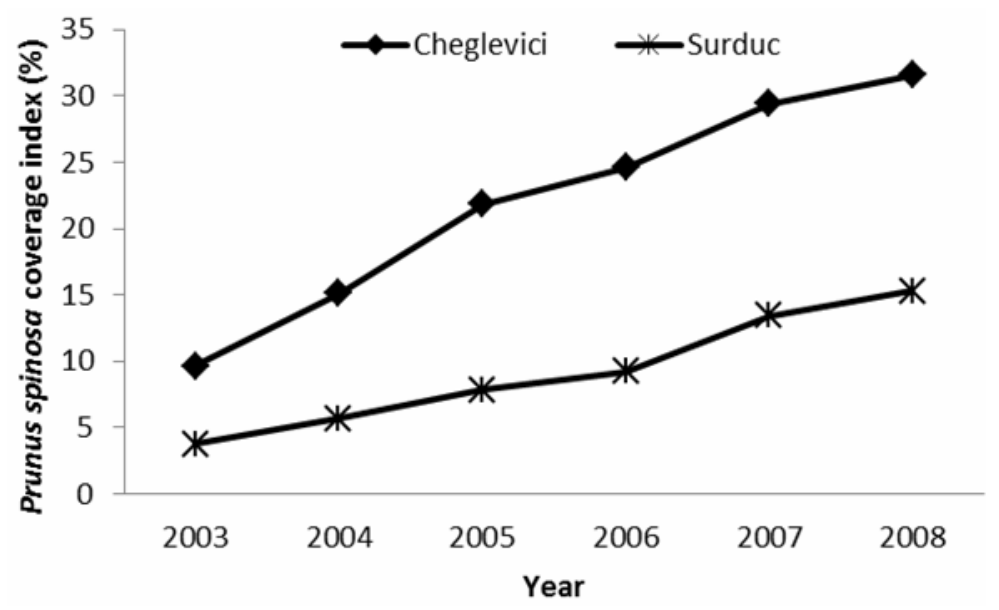

Fig. 1. Evolution in time of P. spinosa coverage index

Table 2. $r$ and $R^{2}$ among $P$. spinosa coverage index and species richness, number of grasses, legumes and other species, contribution of grasses, legumes and other species, $H^{\prime}, D$ and $V P(\alpha=0.05$; onetailed test; $d f=5$; $n s p>0.05, * p<0.05, * * p<0.025, * * * p<0.01$ )

\begin{tabular}{|c|c|c|c|c|c|c|c|c|c|c|c|}
\hline \multirow{2}{*}{\multicolumn{2}{|c|}{ Specification }} & \multirow{2}{*}{$\begin{array}{l}\text { Species } \\
\text { richness }\end{array}$} & \multicolumn{3}{|c|}{ Number of } & \multicolumn{3}{|c|}{$S C \%$} & \multirow{2}{*}{$H^{\prime}$} & \multirow{2}{*}{$D$} & \multirow{2}{*}{$V P$} \\
\hline & & & grasses & legumes & others & grasses & legumes & others & & & \\
\hline \multirow{2}{*}{ Cheglecivi } & $r$ & $0.29^{\mathrm{ns}}$ & $0.02^{\mathrm{ns}}$ & $0.43^{\text {ns }}$ & $0.18^{\mathrm{ns}}$ & $-0.42^{\mathrm{ns}}$ & $0.31^{\mathrm{ns}}$ & $0.43^{\mathrm{ns}}$ & $0.26^{\mathrm{ns}}$ & $-0.11^{\mathrm{ns}}$ & $0.12^{\mathrm{ns}}$ \\
\hline & $R$ & 0.09 & 0.00 & 0.19 & 0.03 & 0.18 & 0.10 & 0.17 & 0.07 & 0.01 & 0.01 \\
\hline \multirow{2}{*}{ Surduc } & $r$ & $-0.83 * * *$ & $0.10^{\mathrm{ns}}$ & $-0.14^{\mathrm{ns}}$ & $-0.66^{*}$ & $-0.66^{*}$ & $-0.32^{\mathrm{ns}}$ & $0.81^{* *}$ & $0.41^{\mathrm{ns}}$ & $-0.61^{\mathrm{ns}}$ & $-0.68^{*}$ \\
\hline & $R^{2}$ & 0.69 & 0.01 & 0.02 & 0.43 & 0.44 & 0.10 & 0.63 & 0.16 & 0.38 & 0.46 \\
\hline
\end{tabular}

The obtained correlation coefficients were different between the analysed grasslands. In the case of grassland from Cheglevici there wasn't any correlation between the analysed variables, even it has a greater coverage index of $P$. spinosa. The correlation coefficients obtained for the grassland from Surduc were the following: strong negative relationship with species richness $(r=-0.83)$, medium strength positive relationship with the contribution of the species from other families $(r=0.81)$, and weak negative relationship with the number of the species from other families $(r=-0.66)$, grasses contribution $(r=-0.66)$ and pastoral value $(r=-0.68)$.

Other researches from literature have shown that the effects of shrub encroachment on plant diversity are ambiguous (PIHLGREN, 2007). Some studies have demonstrated negative effect of shrubs on plant diversity (LINDBORG and ERIKSSON, 2004 cited by PIHLGREN, 2007) and other correlation analyses showed that increasing proportion of the pasture area covered by shrubs had a positive effect on species richness on most taxa (SÖDERSTRÖM et al., 2001). 


\section{CONCLUSIONS}

The encroachment of $P$. spinosa in grasslands has different influence on the vegetation sward, from the point of view of the coverage index of the shrub and the management intensity. At lower coverage indexes $P$. spinosa can determinate the decrease of the species richness, the contribution of the species from other families increasing instead of the decrease of their number of taxa. Also, the increase of the contribution of the taxa from other families is determining a lower pastoral value. Other values of the coverage index aren't determining significant changes on the vegetation cover.

\section{ACKNOWLEDGEMENTS}

This work was published during the project "Postdoctoral School of Agriculture and Veterinary Medicine", POSDRU/89/1.5/S/62371, co-financed by the European Social Fund through the Sectorial Operational Programme for the Human Resources Development 2007-2013.

\section{REFERENCES}

1. Bakker E.S., Olff H., Vandenberghe C., De Maeyer K., Smit R., Gleichman J.M., Vera F.W.M., 2004. Ecological anachronisms in the recruitment of temperate light-demanding tree species in wooded pastures. Journal of Applied Ecology, 41: 571-582.

2. Beals M., Gross L., Harrell S., 2000. Diversity indices: Shannon's H and E. [Internet] The Institute for Environmental Modelling (TIEM), University of Tennessee, USA. http://www.tiem. utk.edu/ gross/bioed/bealsmodules/shannonDI.html, Accessed on 18 March 2011.

3. Daget P., Poissonet J. 1971. Une méthode d'analyse phytologique des prairies. Critéres d'application. Ann. Agron., 22, 1: 5-41.

4. Marakoglu T., Arslan D., ÖzCan M., Haciseferogullari H., 2005. Proximate composition and technological properties of fresh blackthorn (Prunus spinosa L. subsp. dasyphylla (Schur.)) fruits. Journal of Food Engineering, 68, 2: 137-142.

5. PÂRVU C., 2000. Universul plantelor - Mică enciclopedie. Editura Enciclopedică Bucureşti: $1-872$.

6. Pinlgren A., 2007. Small-scale structures and grazing intensity in semi-natural pastures - effects on plants and insects. Doctoral thesis. Swedish University of Agricultural Sciences Uppsala.

7. RAHMANN G., 2004. Utilisation and maintenance of indigenous shrubs in protected open grasslands (Gentiano-Koelerietum) by organic goats keeping. Landbauforschung Völkenrode, 54 (1): $45-50$.

8. Söderström, B., Svensson, B., Vessby K., Glimskär A., 2001. Plants, insects and birds in semi-natural pastures in relation to local habitat and landscape factors. Biodiversity and Conservation, 10: 1839-1863. 


\section{STRESZCZENIE}

\section{Wpływ śliwy tarniny (Prunus spinosa L.) na roślinność trawiastą w zachodniej Rumunii}

Słowa kluczowe: korelacja, Prunus spinosa L., roślinność, skład florystyczny, użytki zielone

Śliwa tarnina (Prunus spinosa L.) jest gatunkiem, który zmienia trwałe użytki zielone w ekosystemy zdominowane przez roślinność krzewiastą. Gatunek jest powszechny w zachodniej Rumunii i trudny do opanowania ze względu na dużą zdolność wegetatywnego rozmnażania z korzeni. Masowe pojawy gatunku w ekosystemach trawiastych spowodowane są zaniechaniem ich użytkowania i zmniejszeniem obsady zwierząt. Roślinność analizowano linową metodą punktowokwadratową. Celem badań była analiza wpływu gatunku na pewne cechy roślinności takie jak bogactwo gatunkowe, liczba i udział gatunków trawiastych, motylkowych i innych, wskaźniki różnorodności gatunkowej (Shannona - H' i Simpsona $D$ ) oraz wartość pastwiskowa VP. 